\title{
Konflik Peran dan Perundungan (Bullying) di Tempat Kerja: Studi Meta- analisis
}

\author{
Ika Adita Silviandari \\ ika.adita.s@ugm.ac.id
}

Fakultas Psikologi, Universitas Gadjah Mada

\begin{abstract}
This study examines the relationship between role conflict and workplace bullying through meta-analysis technique. A total of 11 research articles and 20 research data were studied based on the inclusion criteria of this study and analyzed to find correlations between both variables. The results showed the correlation between role conflict and workplace bullying with $r=0.34$. From the results, it can be said that significant correlation between role conflict and workplace bullying do exist. The estimated correlation value of this study is consistent with previous meta-analysis studies in similar topic.
\end{abstract}

Keywords: meta-analysis; role conflict; workplace bullying

Penelitian ini bertujuan menguji hubungan antara konflik peran dan perundungan (bullying) di tempat kerja melalui teknik meta-analisis. Sebanyak 11 artikel penelitian dan 20 data penelitian diteliti berdasarkan kriteria inklusi dan kemudian dianalisis untuk menemukan korelasi antara kedua variabel tersebut. Hasil meta-analisis menunjukkan bahwa terdapat hubungan antara konflik peran dan perundungan di tempat kerja dengan nilai $r=0.34$. Hasil ini bermakna bahwa terdapat hubungan positif yang signifikan antara konflik peran dan perundungan di tempat kerja. Estimasi nilai korelasi penelitian ini sejalan dan konsisten dengan penelitian meta-analisis sebelumnya dengan topik serupa.

Kata kunci: meta-analisis; konflik peran; perundungan di tempat kerja

Received: January 29, 2018 Accepted: December 12, 2018

How to cite: Silviandari, I. A. (2018). Konflik Peran dan Perundungan (Bullying) di Tempat Kerja: Studi Metaanalisis. MEDIAPSI, 4(2), 58-67. doi:

https://doi.org/10.21776/ub.mps.2018.004.02.1

\section{Pendahuluan}

Pada tahun 1960-an seorang dokter Swedia yaitu Dan Olweus mendeteksi jenis perilaku bermusuhan (hostile), khususnya dalam lingkungan sekolah yang terjadi dalam kurun waktu yang lama. Perilaku ini disebut dengan mobbing atau bullying. Pada awal tahun 1980-an, Profesor Heinz Leymann juga menemukan perilaku bermusuhan dalam jangka panjang yang memiliki karakteristik yang sama dengan penelitian Dan Olweus. Namun fenomena yang diamati Leymann ini terjadi pada karyawan dan tempat kerja mereka. Sejak saat itu Leymann menjadi pakar internasional yang paling terkenal dalam bidang perundungan di tempat kerja (workplace bullying). Leymann dianggap sebagai peneliti pertama dan pelopor dalam penyebaran istilah bullying atau mobbing di Eropa. Perintis Eropa lainnya di bidang ini adalah psikiater Prancis Marie France Hirigoyen dan psikolog Spanyol Iñaki Piñuely Zabala. Leymann memelopori penelitian tentang mobbing di tahun 1980-an. Penelitian di bidang ini awalnya didasarkan pada studi kasus tentang sejumlah perawat yang telah melakukan atau mencoba melakukan bunuh diri karena adanya suatu peristiwa di tempat kerja.

Tidak hanya di Eropa, fenomena perundungan di tempat kerja juga banyak diteliti di Amerika Utara, di mana dari hasil 
penelitian tersebut memunculkan berbagai nama dan istilah yang beragam tentang perundungan, di antaranya adalah abusive disrespect, employee abuse, generalized workplace abuse, workplace aggression, victimization, counter-productive work behavior, deviant behavior, social undermining, petty tyranny, dan workplace incivility (Daniel, 2009).

Daniel (2009) juga mengatakan bahwa perundungan di tempat kerja telah dijelaskan sebagai konsep umum yang meliputi harassment (perilaku yang mengganggu), intimidasi dan agresi atau seringkali violent behavior (perilaku kekerasan). Berbagai istilah digunakan untuk mempelajari konsep yang sebenarnya merupakan satu fenomena ini. Istilah bullying sendiri sering digunakan dalam penelitian di Inggris, Irlandia, Australia, dan negara-negara Eropa bagian barat. Sedangkan pada penelitian di Jerman seringkali digunakan istilah mobbing.

Di Eropa, perundungan di tempat kerja diartikan secara lebih luas yaitu berkaitan dengan sebuah perbedaan pendapat. Hampir 5 sampai 10 persen pekerja di Eropa telah mengalami dan berhadapan dengan perundungan di tempat kerja serta kekerasan dengan tujuan tertentu. Perundungan di tempat kerja terjadi pada segala bentuk organisasi (baik bersifat privat ataupun publik) dan yang menjadi target atau korban terdiri dari laki-laki maupun perempuan, pekerja ataupun pada level manajer (Einarsen, dkk, 2011; Einarsen, dkk, 1994: Glaso, Matthiesen, \& Einarsen, 2007).

Dalam beberapa literatur perundungan di tempat kerja, faktor-faktor yang menjadi penyebab munculnya perundungan masih menjadi perdebatan, terutama ketika faktor tersebut berkaitan dengan pekerjaan. Banyak model dan pendekatan yang digunakan untuk menjelaskan dinamika munculnya perundungan di tempat kerja. Salah satunya adalah model yang dikemukakan oleh Bowling dan Beehr (2006) di mana mereka mengajukan model yang berorientasi pada target untuk menjelaskan terjadinya perundungan di tempat kerja dengan menggunakan analisis pada tingkat individual, dengan fokus pada pengaruh faktor stres sebagai anteseden perundungan.

Stres peran (role stress) di tempat kerja sering diasumsikan terdiri dari tiga konsep yang berbeda namun saling terkait. Pertama, yaitu ambiguitas peran (role ambiguity), yang berarti adanya ketidakpastian tentang tindakan mana yang harus dilakukan karyawan untuk memenuhi harapan akan peran kerja seseorang. Kedua, konflik peran yang muncul ketika ada ketidaksesuaian antara harapan dan tuntutan dari peran kerja seseorang (Beehr, 1995). Ketiga, konsep peran yang berlebih (role overload) yang agak jarang diteliti karena awalnya dipandang sebagai subtipe konflik peran (Kahn, Wolfe, Quinn, Snoek, \& Rosenthal, 1964), namun kemudian dikembangkan sebagai konsep yang berbeda tetapi masih terkait. Role overload dapat dikonseptualisasikan sejauh mana waktu dan sumber daya tersedia terbukti tidak memadai dalam hal memenuhi peran seseorang dan memenuhi harapan dan kewajiban yang terkait dengannya (Beehr, 1995).

Beberapa penelitian cross-sectional telah memberikan bukti bahwa terdapat hubungan yang konsisten antara stresor peran dan perundungan di tempat kerja. Misalnya, Einarsen, Raknes, dan Matthiesen (1994) menemukan bahwa konflik peran berkorelasi relatif kuat dengan perundungan di tempat kerja $(r=0.26)$, sementara korelasi yang lebih 
lemah ditemukan untuk ambiguitas peran $(\mathrm{r}=0.11)$. Pola hubungan yang sama juga diidentifikasi oleh Bowling dan Beehr (2006) dalam meta-analisisnya. Mereka menemukan bahwa konflik peran $(\mathrm{r}=0.44)$ memiliki korelasi yang lebih tinggi dengan perundungan di tempat kerja jika dibandingkan dengan ambiguitas peran $(\mathrm{r}=0.30)$ dan kelebihan peran $(\mathrm{r}=0.28)$.

Sejalan dengan hal tersebut, penelitian ini bertujuan untuk menyelidiki sejauh mana berbagai penelitian tentang hubungan antara konflik peran dan perundungan di tempat kerja dengan mengambil rentang waktu penelitian antara tahun 2007 sampai dengan 2017. Penelitian ini menggunakan pendekatan metaanalisis sebagai metode untuk mengintegrasikan hasil-hasil studi yang sudah pernah dilakukan sebelumnya. Adapun hipotesis dalam penelitian ini adalah terdapat hubungan antara konflik peran dan perundungan di tempat kerja.

\section{Metode}

\section{Pencarian literatur}

Artikel-artikel yang relevan untuk studi meta-analisis ini ditelusuri melalui pangkalan data daring (online database) yaitu EBSCO, ProQuest, Emerald Insight, dan Science Direct, yang dapat diakses melalui laman www.lib.ugm.ac.id. Kata kunci pencarian yaitu role conflict dan workplace bullying. Semua artikel yang relevan kemudian dipertimbangkan menurut kriteria inklusi sebagai syarat untuk dapat digunakan sebagai data meta-analisis.

\section{Kriteria inklusi}

Kriteria seleksi artikel yang digunakan dalam riset ini adalah (1) studi primer yang mengkaji variabel konflik peran dan perundungan di tempat kerja dan juga berbagai istilah lain yang maknanya sama semisal bullying at workplace dan mobbing, dan (2) laporan penelitian pada studi primer mengandung informasi statistik yang diperlukan seperti nilai rerata, standar deviasi, serta nilai $r$ maupun nilai $F$.

Dari 23 artikel yang diperoleh pada tahap awal, terdapat 11 artikel yang meneliti keterkaitan antara konflik peran dan perundungan di tempat kerja. Berdasarkan 11 artikel tersebut terdapat 20 studi, di mana 18 studi merupakan studi korelasional (r) dan 2 studi di antaranya merupakan studi perbandingan dengan analisis varians $(\mathrm{F})$. Dari kedua studi perbandingan tersebut peneliti melakukan transformasi persamaan ke dalam nilai $\mathrm{t}, \mathrm{d}$, dan $\mathrm{r}$.

\section{Prosedur meta-analisis}

Teknik meta-analisis yang digunakan pada penelitian ini mengacu pada prosedur Hunter dan Schmidt (2004) dengan langkah sebagai berikut:

1. Transformasi nilai $F$, dengan mengubah persamaan aljabar dari nilai $\mathrm{F}$ menjadi nilai $\mathrm{t}, \mathrm{d}$, dan $\mathrm{r}$.

2. Bare bones meta-analysis untuk koreksi kesalahan pengambilan sampel, yang dilakukan dengan:

- Menghitung rerata korelasi populasi;

- Menghitung varians $r_{x y}$;

- Menghitung varians kesalahan pengambilan sampel; dan

- Dampak kesalahan pengambilan sampel.

\section{Hasil}

\section{Karakteristik sampel penelitian}

Sampel penelitian yang dibahas dalam riset ini memiliki karakteristik sebagaimana yang tercantum dalam Tabel 1. 


\section{SILVIANDARI}

Tahapan meta-analisis

Transformasi nilai $F$ dengan mengubah persamaan aljabar dari nilai $F$ menjadi $t, d$, dan $r$

Terdapat 2 studi yang merupakan penelitian perbandingan yang menghasilkan nilai $\mathrm{F}$ dan 18 studi yang merupakan penelitian korelasional yang menghasilkan nilai r. Nilai F perlu ditransformasikan terlebih dahulu ke dalam nilai t, d, dan r. Adapun persamaan rumus aljabar disajikan sebagai berikut:

Tabel 1

Karakteristik Sampel Penelitian

\begin{tabular}{|c|c|c|c|c|c|}
\hline No. & Tahun & Peneliti & Studi ke- & Jumlah (N) & Karakteristik \\
\hline 1 & 2010 & $\begin{array}{l}\text { Hauge, L. J., Skogstad, A., \& } \\
\text { Einarsen, S. }\end{array}$ & 1 & 4500 & $\begin{array}{l}\text { Karyawan penuh waktu maupun } \\
\text { paruh waktu di Norwegia }\end{array}$ \\
\hline 2 & 2010 & $\begin{array}{l}\text { Hauge, L. J., Skogstad, A., \& } \\
\text { Einarsen, S. }\end{array}$ & 2 & 1207 & $\begin{array}{l}\text { Karyawan penuh waktu maupun } \\
\text { paruh waktu di Norwegia }\end{array}$ \\
\hline 3 & 2007 & $\begin{array}{l}\text { Hauge, L. J., Skogstad, A., \& } \\
\text { Einarsen, S. }\end{array}$ & 1 & 2348 & Karyawan di Norwegia \\
\hline 4 & 2007 & $\begin{array}{l}\text { Hauge, L. J., Skogstad, A., \& } \\
\text { Einarsen, S. }\end{array}$ & 2 & 2348 & Karyawan di Norwegia \\
\hline 5 & 2007 & $\begin{array}{l}\text { Hauge, L. J., Skogstad, A., \& } \\
\text { Einarsen, S. }\end{array}$ & 3 & 2348 & Karyawan di Norwegia \\
\hline 6 & 2007 & $\begin{array}{l}\text { Hauge, L. J., Skogstad, A., \& } \\
\text { Einarsen, S. }\end{array}$ & 4 & 2348 & Karyawan di Norwegia \\
\hline 7 & 2007 & $\begin{array}{l}\text { Hauge, L. J., Skogstad, A., \& } \\
\text { Einarsen, S. }\end{array}$ & 5 & 2348 & Karyawan di Norwegia \\
\hline 8 & 2010 & $\begin{array}{l}\text { Notelaers, G., Witte, H. D., \& } \\
\text { Einarsen, S. }\end{array}$ & 1 & 6175 & $\begin{array}{l}\text { Karyawan dari } 16 \text { perusahaan di } \\
\text { Belgia }\end{array}$ \\
\hline 9 & 2016 & $\begin{array}{l}\text { Einarsen, S., Skogtad, A., } \\
\text { Rovik, E., Lande, A. B., \& } \\
\text { Nielsen, M. B. }\end{array}$ & 1 & 312 & $\begin{array}{l}\text { Karyawan dari salah satu perusahaan } \\
\text { transportasi besar di Norwegia }\end{array}$ \\
\hline 10 & 2013 & $\begin{array}{l}\text { Guckin, C. M., Lewis, C. A., } \\
\text { Shevlin, M., \& Prentice, G. A }\end{array}$ & 1 & 295 & $\begin{array}{l}\text { Mahasiswa psikologi yang bekerja } \\
\text { baik paruh waktu maupun penuh } \\
\text { waktu di Irlandia Utara dan Inggris }\end{array}$ \\
\hline 11 & 2009 & Baillien, E. \& Witte, H. D. & 1 & 1263 & $\begin{array}{l}\text { Karyawan di Flanders (Belgia) yang } \\
\text { bekerja pada organisasi swasta }\end{array}$ \\
\hline 12 & 2016 & $\begin{array}{l}\text { Baillien, E., Camps, J., } \\
\text { Broeck, A. V., Stouten, J., } \\
\text { Godderis, L., Sercu, M., \& } \\
\text { Witte, H. D. }\end{array}$ & 1 & 2029 & Karyawan di Flemish (Belgia) \\
\hline 13 & 2016 & $\begin{array}{l}\text { Baillien, E., Camps, J., } \\
\text { Broeck, A. V., Stouten, J., }\end{array}$ & 2 & 2029 & Karyawan di Flemish (Belgia) \\
\hline
\end{tabular}




\begin{tabular}{|c|c|c|c|c|c|}
\hline & & $\begin{array}{l}\text { Godderis, L., Sercu, M., \& } \\
\text { Witte, H. D. }\end{array}$ & & & \\
\hline 14 & 2009 & $\begin{array}{l}\text { Hauge, L. J., Skogstad, A., \& } \\
\text { Einarsen, S. }\end{array}$ & 1 & 2359 & Tenaga kerja di Norwegia \\
\hline 15 & 2009 & $\begin{array}{l}\text { Hauge, L. J., Skogstad, A., \& } \\
\text { Einarsen, S. }\end{array}$ & 2 & 2359 & Tenaga kerja di Norwegia \\
\hline 16 & 2011 & $\begin{array}{l}\text { Hauge, L. J., Einarsen, S., } \\
\text { Knardahl, S., Lau, B., } \\
\text { Notelaers, G., \& Skogstad, A. }\end{array}$ & 1 & 685 & $\begin{array}{l}\text { Karyawan dari instansi pemerintah } \\
\text { maupun swasta di Norwegia }\end{array}$ \\
\hline 17 & 2011 & $\begin{array}{l}\text { Hauge, L .J., Einarsen, S., } \\
\text { Knardahl, S., Lau, B., } \\
\text { Notelaers, G., \& Skogstad, A. }\end{array}$ & 2 & 670 & $\begin{array}{l}\text { Karyawan dari instansi pemerintah } \\
\text { maupun swasta di Norwegia }\end{array}$ \\
\hline 18 & 2007 & $\begin{array}{l}\text { Matthiesen, S. B., \& Einarsen, } \\
\text { S. }\end{array}$ & 1 & 2215 & $\begin{array}{l}\text { Karyawan yang merupakan anggota } \\
\text { dari Serikat Pekerja Norwegia dan } \\
\text { Federasi Karyawan Norwegia (NHO) }\end{array}$ \\
\hline 19 & 2017 & $\begin{array}{l}\text { Vranjes, I., Baillien, E., } \\
\text { Vandebosch, H., Erreygers, S., } \\
\text { \& Witte, H. D. }\end{array}$ & 1 & 1650 & $\begin{array}{l}\text { Karyawan yang bekerja pada sektor } \\
\text { publik dan swasta yang ada di Belgia }\end{array}$ \\
\hline 20 & 2017 & $\begin{array}{l}\text { Vranjes, I., Baillien, E., } \\
\text { Vandebosch, H., Erreygers, S., } \\
\text { \& Witte, H. D. }\end{array}$ & 2 & 1650 & $\begin{array}{l}\text { Karyawan yang bekerja pada sektor } \\
\text { publik dan swasta yang ada di Belgia }\end{array}$ \\
\hline
\end{tabular}

Tabel 2

Transformasi Nilai F ke dalam t, d, dan r

\begin{tabular}{|c|c|c|c|c|c|c|c|}
\hline No. & Tahun & Peneliti & $\mathbf{N}$ & $\mathbf{F}$ & $\mathbf{t}$ & d & $\mathbf{r}_{\mathbf{x y}}$ \\
\hline 1 & 2010 & Hauge, L. J., Skogstad, A., \& Einarsen, S. & 4500 & & & & 0.49 \\
\hline 2 & 2010 & Hauge, L. J., Skogstad, A., \& Einarsen, S. & 1207 & & & & 0.50 \\
\hline 3 & 2007 & Hauge, L. J., Skogstad, A., \& Einarsen, S. & 2348 & & & & 0.48 \\
\hline 4 & 2007 & Hauge, L. J., Skogstad, A., \& Einarsen, S. & 2348 & & & & 0.37 \\
\hline 5 & 2007 & Hauge, L. J., Skogstad, A., \& Einarsen, S. & 2348 & & & & 0.50 \\
\hline 6 & 2007 & Hauge, L. J., Skogstad, A., \& Einarsen, S. & 2348 & & & & 0.17 \\
\hline 7 & 2007 & Hauge, L. J., Skogstad, A., \& Einarsen, S. & 2348 & & & & 0.20 \\
\hline 8 & 2010 & Notelaers, G., Witte, H. D., \& Einarsen, S. & 6175 & & & & 0.43 \\
\hline 9 & 2016 & $\begin{array}{l}\text { Einarsen, S., Skogtad, A., Rovik, E., Lande, A. B., \& } \\
\text { Nielsen, M. B. }\end{array}$ & 312 & & & & 0.39 \\
\hline 10 & 2013 & $\begin{array}{l}\text { Guckin, C. M., Lewis, C. A., Shevlin, M., \& Prentice, G. } \\
\text { A. }\end{array}$ & 295 & 2.66 & 1.63 & 0.19 & 0.09 \\
\hline 11 & 2009 & Baillien, E. \& Witte, H. D. & 1263 & & & & 0.39 \\
\hline 12 & 2016 & $\begin{array}{l}\text { Baillien, E., Camps, J., Broeck, A. V., Stouten, J., } \\
\text { Godderis, L., Sercu, M., \& Witte, H. D. }\end{array}$ & 2029 & & & & 0.23 \\
\hline 13 & 2016 & $\begin{array}{l}\text { Baillien, E., Camps, J., Broeck, A. V., Stouten, J., } \\
\text { Godderis, L., Sercu, M., \& Witte, H. D. }\end{array}$ & 2029 & & & & 0.34 \\
\hline 14 & 2009 & Hauge, L. J., Skogstad, A., \& Einarsen, S. & 2359 & & & & 0.12 \\
\hline 15 & 2009 & Hauge, L. J., Skogstad, A., \& Einarsen, S. & 2359 & & & & 0.19 \\
\hline
\end{tabular}




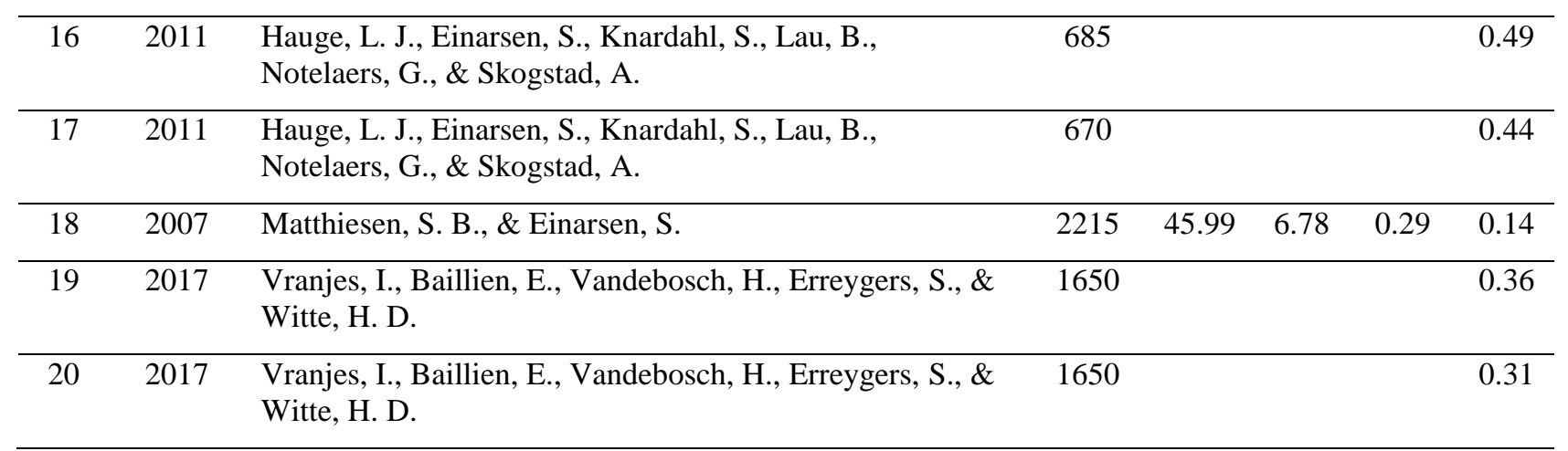

Tabel 3

Koreksi Kesalahan Sampling

\begin{tabular}{|c|c|c|c|}
\hline No. Studi & $\mathbf{N}$ & $\mathbf{r i}_{\mathbf{i}}$ & $\mathbf{N}_{\mathrm{i}} \mathbf{r}_{\mathbf{i}}$ \\
\hline 1 & 4500 & 0.49 & 2205 \\
\hline 2 & 1207 & 0.50 & 603.5 \\
\hline 3 & 2348 & 0.48 & 1127.04 \\
\hline 4 & 2348 & 0.37 & 868.76 \\
\hline 5 & 2348 & 0.50 & 1174 \\
\hline 6 & 2348 & 0.17 & 399.16 \\
\hline 7 & 2348 & 0.20 & 469.6 \\
\hline 8 & 6175 & 0.43 & 2655.25 \\
\hline 9 & 312 & 0.39 & 121.68 \\
\hline 10 & 295 & 0.09 & 26.55 \\
\hline 11 & 1263 & 0.39 & 492.57 \\
\hline 12 & 2029 & 0.23 & 466.67 \\
\hline 13 & 2029 & 0.34 & 689.86 \\
\hline 14 & 2359 & 0.12 & 283.08 \\
\hline 15 & 2359 & 0.19 & 448.21 \\
\hline 16 & 685 & 0.49 & 335.65 \\
\hline 17 & 670 & 0.44 & 294.8 \\
\hline 18 & 2215 & 0.14 & 310.1 \\
\hline 19 & 1650 & 0.36 & 594 \\
\hline 20 & 1650 & 0.31 & 511.5 \\
\hline Jumlah & 41138 & & 14076,98 \\
\hline Rerata & & & 0.34 \\
\hline
\end{tabular}

Koreksi kesalahan pengambilan sampel (bare bone meta-analysis)

Apabila korelasi populasi diasumsikan konstan di antara beberapa penelitian, maka estimasi terbaik dari korelasi bukanlah rerata sederhana dari korelasi beberapa penelitian tersebut, akan tetapi merupakan rerata yang dibobot untuk masing-masing korelasi yaitu dibagi dengan jumlah sampel dalam studi (Hunter \& Schmidt, 2004). Estimasi terbaik untuk korelasi populasi adalah dengan mengkuti persamaan sebagai berikut:

- Rerata korelasi populasi

Persamaan yang digunakan adalah untuk menghitung rerata korelasi populasi adalah:

$$
\overline{\mathrm{r}}=\frac{\Sigma\left[N_{i} r_{i}\right]}{\Sigma N_{i}}
$$

Langkah selanjutnya adalah mengubah nilai $r$ atau $r_{x y}$ pada masing-masing studi untuk mendapatkan rerata korelasi populasi, di mana penelitian meta-analisis menghasilkan estimasi rerata korelasi populasi setelah dikoreksi dengan jumlah sampel $(\overline{\mathrm{r}})$ adalah 0.34 . Hasil tersebut sebagaimana tersaji pada Tabel 3.

Tabel 3

Koreksi Kesalahan Sampling

- Menghitung varians $r_{x y}\left(\sigma^{2} r\right)$

Varians $r_{x y}$ atau $\sigma^{2} r$ dihitung dengan persamaan sebagai berikut:

$$
\sigma^{2} \mathrm{r}=\frac{\Sigma\left[N_{i}\left(r_{i}-\bar{r}\right)^{2}\right]}{\sum N}
$$


Hasil perhitungan varians $\mathrm{r}_{\mathrm{xy}}$ disajikan dalam Tabel 4, di mana dari perhitungan tersebut diketahui bahwa varians $r_{x y}$ atau $\sigma^{2} r$ adalah 0.01777 .

Tabel 4

Varians $r_{x y}$

\begin{tabular}{|c|c|c|c|c|c|}
\hline $\begin{array}{c}\text { No. } \\
\text { Studi }\end{array}$ & $\mathbf{N}$ & $\mathbf{r}_{\mathbf{i}}$ & $\left(\mathbf{r}_{\mathbf{i}}-\overline{\mathbf{r}}\right)$ & $\left(\mathbf{r}_{\mathbf{i}}-\overline{\mathbf{r}}\right)^{2}$ & $\mathbf{N}\left(\mathbf{r}_{i}-\overline{\mathbf{r}}\right)^{2}$ \\
\hline 1 & 4500 & 0.49 & 0.147811 & 0.021848 & 98.31612 \\
\hline 2 & 1207 & 0.50 & 0.157811 & 0.024904 & 30.05942 \\
\hline 3 & 2348 & 0.48 & 0.137811 & 0.018992 & 44.59277 \\
\hline 4 & 2348 & 0.37 & 0.027811 & 0.000773 & 1.816036 \\
\hline 5 & 2348 & 0.50 & 0.157811 & 0.024904 & 58.47516 \\
\hline 6 & 2348 & 0.17 & -0.17219 & 0.029649 & 69.61615 \\
\hline 7 & 2348 & 0.20 & -0.14219 & 0.020218 & 47.47133 \\
\hline 8 & 6175 & 0.43 & 0.087811 & 0.007711 & 47.61378 \\
\hline 9 & 312 & 0.39 & 0.047811 & 0.002286 & 0.713192 \\
\hline 10 & 295 & 0.09 & -0.25219 & 0.063599 & 18.76182 \\
\hline 11 & 1263 & 0.39 & 0.047811 & 0.002286 & 2.887055 \\
\hline 12 & 2029 & 0.23 & -0.11219 & 0.012586 & 25.53785 \\
\hline 13 & 2029 & 0.34 & -0.00219 & 0.000479 & 0.009724 \\
\hline 14 & 2359 & 0.12 & -0.22219 & 0.049368 & 116.4592 \\
\hline 15 & 2359 & 0.19 & -0.15219 & 0.023162 & 54.63811 \\
\hline 16 & 685 & 0.49 & 0.147811 & 0.021848 & 14.9659 \\
\hline 17 & 670 & 0.44 & 0.097811 & 0.009567 & 6.409856 \\
\hline 18 & 2215 & 0.14 & -0.20219 & 0.040880 & 90.55026 \\
\hline 19 & 1650 & 0.36 & 0.017811 & 0.000317 & 0.52342 \\
\hline 20 & 1650 & 0.31 & -0.03219 & 0.001036 & 1.70964 \\
\hline Total & 41138 & & & & 731.1268 \\
\hline Mean & 2056.9 & & & & 36.55634 \\
\hline $\operatorname{Var} r_{x}$ & & & & & 0.01777 \\
\hline
\end{tabular}

- Varians kesalahan pengambilan sampel

Varians $r_{x y}$ sebesar 0.01777 merupakan campuran dari dua hal yaitu variasi dalam korelasi populasi dan variasi dalam korelasi sampel yang dihasilkan oleh kesalahan sampling. Estimasi varians dalam korelasi populasi dapat diperoleh hanya dengan mengkoreksi varians yang teramati untuk kesalahan pengambilan sampel (Hunter \& Schmidt, 2004). Varians kesalahan pengambilan sampel dapat diestimasi dengan menggunakan persamaan di bawah ini:

$$
\sigma^{2} \mathrm{e}=\frac{\left((1-\overline{\mathrm{r}})^{2}\right)^{2}}{(\bar{N}-1)}
$$

Berdasarkan nilai $\overline{\mathrm{r}}$ yang diperoleh dan rerata jumlah sampel $\mathrm{N}$, maka varians kesalahan sampling pada penelitian metaanalisis ini adalah sebesar 0.00038 , dengan perhitungan sebagai berikut:

$$
\begin{aligned}
& \sigma^{2} \mathrm{e}=\frac{\left((1-0.34)^{2}\right)^{2}}{(\overline{2056.9}-1)} \\
& \sigma^{2} \mathrm{e}=0.00038
\end{aligned}
$$

\section{- Interval kepercayaan}

Jika korelasi populasi setelah dikoreksi dengan jumlah sampel $(\overline{\mathrm{r}})$ memiliki distribusi normal, maka interval kepercayaan dapat dihitung dengan persamaan berikut:

$$
\begin{aligned}
& \overline{\mathrm{r}} \pm 1.96 \mathrm{SD} \\
& \overline{\mathrm{r}} \pm 1.96 \sqrt{ } \sigma^{2} \mathrm{r}
\end{aligned}
$$

Sehingga diperoleh hasil sebagai berikut ini:

$$
\begin{aligned}
& \overline{\mathrm{r}} \pm 1.96 \sqrt{0.01739} \\
& \overline{\mathrm{r}} \pm 1.96(0.13188) \\
& \overline{\mathrm{r}} \pm 0.25848 \\
& 0.34 \pm 0.25848 \\
& 0.08152<\overline{\mathrm{r}}<0.59848
\end{aligned}
$$

- Dampak kesalahan pengambilan sampel

Dampak kesalahan pengambilan sampel dapat diketahui dengan menggunakan persamaan berikut:

$$
=\frac{\sigma^{2} e}{\sigma^{\Sigma} \rho} 100 \%
$$




$$
\begin{aligned}
& =\frac{\sigma^{2} e}{\sigma^{2} r-\sigma^{2} e} 100 \% \\
& =\frac{0.00038}{0.01739} 100 \% \\
& =2.18 \%
\end{aligned}
$$

Faktor kesalahan lain yang belum terspesifikasi sebesar 97.82 persen.

\section{Diskusi}

Korelasi populasi yang sesungguhnya setelah dikoreksi oleh kesalahan sampel diestimasi sebesar 0.34, varians populasi sebesar 0.01739, dan standar deviasi (SD) sebesar 0.13188. Interval kepercayaan dengan taraf 95 persen berada pada batas penerimaan antara $0.08152<\overline{\mathrm{r}}<0.59848$. Pada penelitian ini, nilai $\overline{\mathrm{r}}$ sebesar 0,34 artinya nilai korelasi berada diantara batas interval kepercayaan untuk diterima, sehingga dapat dikatakan bahwa hipotesis yang menyatakan ada hubungan hubungan antara konflik peran dan bullying di tempat kerja dapat diterima.

Berdasarkan hasil analisis data tersebut diketahui bahwa hubungan antara konflik peran dan perundungan di tempat kerja berada pada kategori sedang dengan nilai korelasi sebesar 0.34. Makna dari hasil ini adalah benar terbukti bahwa konflik peran berhubungan dengan perundungan di tempat kerja. Hubungan tersebut telah dapat diduga sebelumnya dengan melihat bahwa korelasi dari beberapa penelitian yang digunakan dalam kajian meta-analisis ini menunjukkan nilai yang lebih kecil.

Penelitian meta-analisis ini menggunakan data riset 10 tahun terakhir yaitu antara tahun 2007 sampai dengan 2017. Salah satu pertimbangan digunakannya data riset setelah tahun 2007 adalah karena pada tahun sebelumnya (2006), studi meta-analisis mengenai hubungan konflik peran dan perundungan di tempat kerja telah dilakukan oleh Bowling dan Beehr (2006). Apabila ditinjau dari hasil penelitian meta-analisis sebelumnya yang dilakukan Bowling dan Beehr (2006), maka penelitian ini memiliki hasil yang dapat dikatakan cukup konsisten.

Hasil penelitian ini dapat memberikan gambaran mengenai kekuatan hubungan antara konflik peran dan perundungan di tempat kerja. Untuk mempertajam penelitian tentang topik ini maka masih ada hal lain yang perlu diperhatikan dan dapat dilakukan oleh peneliti selanjutnya. Hal ini dikarenakan pada penelitian ini, 11 artikel yang telah dianalisis memiliki karakteristik responden yang cukup homogen yaitu karyawan atau tenaga kerja yang berada di kawasan Eropa saja (Inggris, Norwegia, dan Belgia), sehingga tingkat generalisasi hasil penelitian ini untuk kawasan Asia, Afrika, Amerika, dan lain sebagainya masih perlu dikaji lagi. Hal ini penting untuk menjadi perhatian peneliti selanjutnya karena fenomena perundungan di tempat kerja tidak terlepas dari latar belakang budaya.

\section{Daftar Pustaka}

Baillien, E., \& Witte, H. D. (2009). Why is organizational change related to workplace bullying? Role conflict and job insecurity as mediators. Economic and Industrial Democracy, 30(3), 348371.

doi: https://doi.org/10.1177/0143831X09336 $\underline{557}$

Baillien, E., Camps, J., Broeck, A. V., Stouten, J., Godderis, L., Sercu, M., \& Witte, H. D. (2016). An eye for an eye will make the whole world blind: Conflict escalation into workplace bullying and the role of distributive conflict behavior. 
Journal of Bussiness Ethics, 137(2), 415-429. doi: http://dx.doi.org/10.1007/s10551-0152794-y

Beehr, T. A. (1995). Psychological Stress in the Workplace. London: Routledge.

Bowling, N. A., \& Beehr, T. A. (2006). Workplace harassment from the victim's perspective: A theoretical model and meta-analysis. Journal of Applied Psychology, 91(5), 998-1012. doi: http://dx.doi.org/10.1037/0021$\underline{9010.91 .5 .998}$

Daniel, T. A. (2009). Stop Bullying at Work. Virginia: Society For Human Resource Management.

Einarsen, S., Raknes, B. I., \& Matthiesen, S. B. (1994). Bullying and harassment at work and their relationship to work environment quality: An exploratory study. European Work and Organizational Psychologist, 4(4), 381402. doi: https://doi.org/10.1080/1359432940841 $\underline{0497}$

Einarsen, S., Hoel, H., Zapf, D., \& Cooper, C. L. (2011). Bullying and Harrasment in the Workplace. London: Taylor \& Francis.

Einarsen, S., Skogtad, A., Rovik, E., Lande, A. B., \& Nielsen, M. B. (2016). Climate for conflict management, exposure to workplace bullying and work engagement: A moderated mediation analysis. The International Journal of Human Resource Management, 29(3), 549-570. doi: https://doi.org/10.1080/09585192.2016. 1164216
Guckin, C. M., Lewis, C. A., Shevlin, M., \& Prentice, G. A. (2013). Experiences of workplace bullying among 'nontraditional' students: Cause for concern for both business and education? Psychology, Society, \& Education, 5(2), 103-124. Retrieved from: https://dialnet.unirioja.es/servlet/articul o? codigo $=4761656$

Glas $\varnothing$, L., Matthiesen, S. B., Nielsen, M. B., \& Einarsen, S. (2007). Do targets of workplace bullying portray a general victim personality profile? Scandinavian Journal of Psychology, 48(4), 313-319. doi: https://doi.org/10.1111/j.14679450.2007.00554.x

Hauge, L. J., Skogstad, A., \& Einarsen, S. (2010). Role stressors and exposure to workplace bullying: Causes or consequences of what and why? European Journal of Work and Organizational Psychology, 20(5), 610$630 . \quad$ doi: https://doi.org/10.1080/1359432X.2010. $\underline{482264}$

Hauge, L. J., Skogstad, A., \& Einarsen, S. (2007). Relationships between stressful work environments and bullying: Results of a large representative study. Work \& Stress, 21(3), 220-242. doi: https://doi.org/10.1080/0267837070170 $\underline{5810}$

Hauge, L. J., Skogstad, A., \& Einarsen, S. (2009). Individual and situational predictors of workplace bullying: Why do perpetrators engage in the bullying of others? Work \& Stress, 23(4), 349-358. doi:

http://dx.doi.org/10.1080/02678370903 $\underline{395568}$ 
Hauge, L. J., Einarsen, S., Knardahl, S., Lau, B., Notelaers, G., \& Skogstad, A. (2011) Leadership and role stressors as departmental level predictors of workplace bullying. International Journal of Stress Management, 18(4), 305-323. doi: http://dx.doi.org/10.1037/a0025396

Hunter, J. E., \& Schmidt, F. L. (2004). Methods of Meta-Analysis: Correcting Error and Bias in Research Findings. Newbury Park: Sage Publications.

Kahn, R. L., Wolfe, D. M., Quinn, R. P., Snoek, D. J., \& Rosenthal, R. A. (1964). Organizational Stress: Studies in Role Conflict and Ambiguity. New York: Wiley.

Leymann, H. (1996). The content and development of mobbing at work. European Journal of Work and Organizational Psychology, 5(2), 165184.

doi:

https://doi.org/10.1080/1359432960841 $\underline{4853}$

Matthiesen, S. B., \& Einarsen, S. (2007). Perpetrators and targets of bullying at work: Role stress and individual differences. Violence and Victims, 22(6), 735-753.

doi: https://doi.org/10.1891/0886670077827 $\underline{93174}$

Notelaers, G., Witte, H. D., \& Einarsen, S. (2010). A job characteristics approach to explain workplace bullying. European Journal of Work and Organizational Psychology, 19(4), 487-504. doi: https://doi.org/10.1080/1359432090300 $\underline{7620}$

Riyono, B. (2008). Intrinsic motivation dan performance: Studi meta analisis.
Psikologika, 13(25), 5-14. Retrieved from:

http://journal.uii.ac.id/index.php/Psikol ogika/article/view/8575

Salin, D. (2004, June). Organisational measures against workplace bullying: The view of business professionals. Paper presented at the 4th International Conferences on Bullying and Harassment in the Workplace, Bergen, Norway. Retrieved from: http://hdl.handle.net/1956/2383

Vranjes, I., Baillien, E., Vandebosch, H., Erreygers, S., \& Witte, H. D. (2017). When workplace bullying goes online: Construction and validation of the Inventory of Cyberbullying Acts at Work (ICA-W). European Journal of Work and Organizational Psychology, 27(1), 28-39. doi: https://doi.org/10.1080/1359432X.2017. $\underline{1363185}$ 